\title{
COVID-19: Implications for the Residential Real Estate Market in Russian Federation
}

\author{
Tretyachenko T. Pivovarova G. ${ }^{*}$ Sogomonyan S.
}

\author{
Rostov state University of Economics (RINH), Rostov-on-don, Russia \\ *Corresponding author. Email: gbp@list.ru
}

\begin{abstract}
The article is devoted to the problem of development of the construction market of residential real estate in Russia in the conditions of the crisis caused by the COVID-19 pandemic. The global coronavirus outbreak provoked one of the deepest crises since the Great Depression. Sanitary force majeure caused by COVID-19 caused not only recession of the global economy, but also of national economic systems [1]. The pandemic and related restrictive measures have also affected many areas of the domestic economy, and the real estate market was no exception. To understand how soon the development sector will be able to adapt to the new realities, it is necessary to give a forecast of the main trends that will be observed in the construction sector of Russia and specifically in the housing construction sector, as well as in related areas of the country's economy.

The main results of the study include: highlighting the characteristics of the housing construction sector that have emerged on the eve of the COVID-19 pandemic crisis, under conditions of a shock period of income recovery and the outlines of possible directions of housing construction development in the near future.

As a result of the study, the following conclusions were drawn: the protection of one of the systems for the reproduction of "human capital" in the face of the "pandemic effect" should be guaranteed by a housing support programme, financial assistance for specific construction projects with the transfer of a share of constructed housing to the State as security for its repayment obligations.
\end{abstract}

Keywords: personal income, development sector, housing construction, crisis, real estate, pandemic, market, standard of living

\section{INTRODUCTION}

Relevance of the problem under study is due to the fact that the construction industry is a driver of the national economy, because by providing citizens with their own housing, improving infrastructure, communication between regions, contributes to the economic growth of the country, improve its welfare and, as a consequence, ensure national security. The peculiarity of the current stage of economic development is that the situation with COVID-19 overlapping the processes of change of technological and world economic patterns, which are so resonantly increasing the crisis phenomena. Under the influence of the pandemic and related restrictive measures, entropy has increased as a measure of chaos and uncertainty in the development of housing construction (all indicators characterizing construction activities have collapsed vertically, including the indicators of the first row: demand for construction services, the volume of construction work carried out and the financial component), which will directly affect the state of the residential real estate market and the possibility of creating a normal environment for the population. At present, it would be somewhat premature to assess the impact of the crisis, but the impact of previous crises can serve as a baseline. From the authors' point of view, a more objective assessment can be made after a more thorough analysis of all factors of the current crisis, taking into account the situation in each region of the country in the second half of 2020, when the impact of the crisis on the development sector will become more pronounced. Meanwhile, the importance of the study at this stage already lies in the formation of a theoretical basis for management decisions on the part of the state in the housing sector, to establish them the rules of the game, adequate to the era of ontological rift between chaos and order, reinforced by the situation with COVID-19.

\section{MATERIALS AND METHOD}

Problems of formation and development of the Russian building market were studied in works of domestic authors O. A. Guzhova [2,3], Yu. A. Pravdina [4], E. O. Proshkina and A. V. Tumashova [5]. The basic accent in the presented works is made on existing territorial distinctions in maintenance of a social and industrial infrastructure which condition defines conditions of development of the building market, presence of considerable risks which are 
high for domestic building branch even in conditions of stable economic development of the country.

The significance and scale of the problems of the construction industry were raised in the works of such domestic and foreign scientists and practitioners as James G. March (1992), George P. Huber (2003), Jeffrey S. Russell (2003), E.P.Zhavoronkov (1996), V.N.Stakhanov (2001) [6-10].

Conceptual foundations for the formation of new conditions for economic entities, which have to constantly survive and ensure the progressive movement forward in a particularly complex trajectory of the national economy, were considered by foreign and domestic scientists Weldon G.. [11], Glazyev S. [12; 13], G.P. Zhuravleva and N.V. Manokhina. [14], Kirdina S. [15], Livshitz V. [16], Olsevich Y. [17],

However, it should be noted that there is no systematic approach to addressing the organization of the housing and development sector in an environment of high uncertainty about the future, where the probability of reaching the bifurcation point of the economic system and/or of breaking down under the impact of the COVID-19 pandemic is greater than ever.

In order to eliminate methodological gaps in the theoretical understanding of changes that characterize the construction industry and its housing sector, the development sector under the conditions of COVID-19, we consider it relevant and timely to conduct research on the problems and existing conditions that can cause degradation and even destruction of the housing sector and the collapse of the residential real estate market.

As the basic methods of research of a problem of the organization of activity of the enterprises of sector of housing construction and development sector in the conditions of intensification of growth of economic and sanitary uncertainty national scientific methods of cognition and private experimental methods, such as system and complex approaches, dialectical method of scientific cognition, comparative-analytical and situational analysis were used.

\section{RESULTS}

The international rating agency Standard \& Poor's Global Ratings notes that in most countries of the world, including Russia, the peak of the pandemic is either near or passed, but COVID-19 will remain a threat until at least the end of 2021, which is associated with the development and availability of the vaccine to a wide range of the world's population [18]. The impact of COVID-19 on all sectors of the domestic economy was quite strong (for example, in the housing sector, a number of indicators indicate that during the period of strict restrictive measures, when 44 regions had restrictions on construction work, and in two - Moscow and Moscow region construction was stopped completely for almost a month, according to the Federal State Statistics Service, the volume of commissioning of the total area of residential premises compared with the corresponding period in 2019, the Entrepreneurial Confidence Index showed a decline of almost $25 \%$. The situation in the residential construction sector was boomerang and affected the residential real estate market).

The current pandemic is a crisis caused by the introduction of sanitary force majeure, which is larger than the Great Recession of 2008-2009, and its depth is comparable to the losses of the European and US economies during the Second World War or the Great Depression of the 30s.

In this regard, it is possible to draw a historical analogy, which will make it possible to identify possible risks, to understand what will happen to the housing sector in the conditions of a growing crisis, to model the conditions for the development of the situation, which will make it possible to avoid a sharp decline in housing construction and stagnation of the development sector.

Before drawing an analogy of the current situation with the crises of 1998, 2008 and 2014 and making forecasts for the development of the residential real estate market, it should be noted that, unlike the previous shocks, the current crisis is not accompanied by the "overheating" of the economy and the imbalance of the ruble exchange rate, there are no risks caused by the cyclical contraction of the economy, and the dynamics of the domestic economic system except for quarantine measures (announcement at the state level for all economic entities of a non-working period of working days in April and May 2020 and suspension of work before the crisis). At the same time, it is important to remember that the speed of recovery of all the sectors of the Russian economy, including those researched in this article, to a large extent depends on the rate of decline in prices and volumes of Russian oil and gas exports, because there is a high dependence of domestic demand and investment activity on the revenues from oil and gas exports to the country.

Over the last two decades the sharp drop of oil prices at the world market has repeatedly had a serious negative impact on the situation in the Russian economy (crises of $1998,2008,2014)$, which was reflected in the state of the residential real estate market.

The technical default of August 1998, when the Russian government introduced a moratorium on repayment of foreign debts by domestic banks and forced restructuring of debts on state securities, was the first serious blow to the Russian housing market.

During this period, the development market was only in its infancy, new buildings were practically not built, as developers were unable to obtain project financing, and the mortgage institution had not yet been formed (the Federal Law "On Mortgage (Pledge of Real Estate)" was signed by the President of Russia and published on July 16, 1998) [20], so the secondary housing market was the main blow. The crisis led to an outflow of expats, who mainly rented apartments in Moscow, which led to a drop in prices and demand in this market and led to the suspension of all transactions in this market for a certain period. In addition, the default led to a temporary correction of the housing market, when housing prices fell by $30 \%$ (from $\$$ 1,000 per 1 sq. m. to $\$ 700$ per 1 sq. m., for comparison: at the historical maximum - before the crisis in 2008 , housing 
prices were about $\$ 6,200$ per 1 sq. m.). The residential real estate market has recovered only by $2002-2003$. The crisis spurred the development of the real estate market. Active mass residential development has started.

The crisis of 2008, as well as the crisis of 1998, was a consequence, including internal problems of the Russian economy, although the trigger was the mortgage crisis in the U.S., which crossed the borders of national economies and covered the entire world economy, including Russia. The price per barrel of Urals oil fell from \$132.1 to \$39.1, the average monthly rate of industrial decline in the domestic economy fell to $3.6 \%$, which theoretically characterizes an acute and deep phase of recession, and Russia's foreign debt reached 30\% of GDP. During this period, the growth rate of household income compared to previous periods experienced a significant decline. This was followed by tougher requirements of banks to borrowers, which led to a slowdown in mortgage development. In addition, 66.0 million square metres were planned to be commissioned in 2008, but 64.1 million square metres, or $97.1 \%$, were actually commissioned. In 2009, 59.8 million square metres were put into operation, which is $6.71 \%$ less than in 2008 .

All these factors could not but affect the development of the real estate market. The number of purchase and sale transactions in 2009 decreased by $16.5 \%$ as compared to pre-crisis 2007 (according to Rosreestr, in 2007 there were 2,326 million purchase and sale transactions between individuals, and in 2009 only 1,943 million housing purchase and sale agreements were concluded).

By the beginning of the crisis in 2008 the real estate market changed a lot. Ten years after the 1998 crisis, the housing market was complemented by a new sector houses under construction - and it was this sector that was hit hard by the crisis in 2008. All sources of financing for construction projects were significantly affected.

A relatively rapid recovery, which was not observed after the collapse of 1998, was also a feature of the 2008 crisis. Already in 2011, the residential property market began to function as normal. Despite the decline in housing commissioning in 2010, when only $58.4 \mathrm{mn}$ sq $\mathrm{m}$ was put into operation, which is $2.34 \%$ less than in 2009 , mortgage loans grew 10 times or more during this period.

Another crisis faced by the Russian economy (commodity dependence, low level of domestic consumption, lack of available sources of financing, drop in oil prices) erupted in 2014, it became a new stage of recession and a continuation of the 2008 crisis. However, unlike the crisis of 2008, it was protracted. The events in Ukraine and the accompanying foreign policy crisis played a special role in weakening the Russian economy. Some economists believe that the new recession was a direct continuation of the 2008 crisis. It resulted in a slowdown in GDP growth that took place throughout the year and, for the first time since 2009, went into negative territory. The ruble lost $70 \%$ of its value during this period, while the refinancing rate set by the Central Bank of Russia reached $17 \%$, and the investment process in the economy practically stopped. The crisis of 2014 was of a different, more systemic nature; during this period the real estate market was influenced by two trends: a fall in solvent demand and an increase in construction costs. The real estate market reacted to the next round of the crisis in the same way as in previous years: reduced demand, lower construction rates, lower ruble prices, which, taking into account the drop in living standards, actually increased for most buyers. A new phenomenon was the growth in the value of mortgage lending, which actually pulled out housing construction under recession.

The negative impact of the crisis on the real estate market was also manifested in the fact that starting from 2016, the volumes of housing commissioning are decreasing: in 2016 - $80.2 \mathrm{mln}$ sq $\mathrm{m}$, in 2017 - $78.6 \mathrm{mln} \mathrm{sq} \mathrm{m}$, in 2018 $75.7 \mathrm{mln} \mathrm{sq} \mathrm{m}$. The number of mortgage transactions is shrinking: while in 2014 the share of mortgage transactions reached $45 \%$, in 2015 it was about $20-25 \%$. At the beginning of summer 2015, approximately $40-50 \%$ of residential properties on the secondary market were sold at a discount, while in autumn their share reached $90 \%$ and the average discount was $7 \%[21,22,23,24]$.

The year 2019 was a turning point in the residential real estate market, in the middle of which the social problem of "deceived shareholders" became particularly acute, which was reinforced by the norms of Federal Law FZ-214 [25], which allowed developers to use the shareholders' funds for other purposes.

To address this issue, the law was amended and fully enacted in July 2019. The amendments allowed to solve the problem of "deceived shareholders", but at the same time increased the cost of construction, which further aggravated the problem of affordability of housing for citizens of Russia (many developers to maintain the rate of profit increased the price of housing. The increase in the price of a sq. $\mathrm{m}$. of residential property on the primary market amounted to $3.62 \%$, which resulted in a $1.69 \%$ drop in sales volumes.

It is not yet possible to fully assess the impact of the changes in the legislation, as most of the projects, before the introduction of restrictions related to the pandemic, were implemented in accordance with the old law, but in the medium term it was forecasted that the tightening of the law FZ-214 will lead to a reduction in construction volumes, withdrawal of many companies from the market, monopolization, and as a result - to a decrease in competition and quality of construction (for example, the volume of construction, which formed on 01.04.2020, is lower by $10.7 \%$ compared to last year).

The changes in the legislation that were adopted in the post-crisis period, when the country's economy has not yet reached the pre-crisis indicators, are a very serious test for the real estate market, the situation on which is significantly aggravated by the crisis that has occurred in 2020 [26].

Let us consider in detail the main factors and conditions of the economic crisis in 2020 and their impact on the parameters of the residential real estate market recovery forecast.

Experts predicted the onset of another global cyclical crisis as early as 2014, citing recapitalization of the existing markets and strengthening of monopolization of the 
economic space as the main reasons for it, but the reason for the global economic crisis in 2020 was the spread of coronavirus infection.

With oil prices falling (average annual oil prices are forecast to stop at \$25 per barrel or even lower in the near future) and the level of gross domestic product (a 10-20\% fall is forecast), there is a potential danger for all sectors of the Russian economy. For Russia, 2020 could be the worst year since 1992, when according to the World Bank's data, the GDP level fell by $14.5 \%$ (during the 1998 crisis, Russia's GDP was estimated to fall by $5.3 \%$, and in 2009. в 8\%) [27].

A number of economists believe that the consequences of the quarantine restrictions imposed on the economy are close in nature to the situation of the early 1990s, when the country's transition from the administrative-planned system of economy to the market conditions of economic management has resulted in the rupture of the existing ties. When forecasting the consequences of the introduced restrictions it is necessary to take into account that for Blanchard and Kremer the depth and duration of the recession largely depend on the complexity of the production chain. Since production chains in sectors affected by significant 'pandemic' constraints are mostly simple and short, it can be assumed that a recovery can take place relatively quickly, since the duration of the recovery is determined solely by the time limits of the constraints imposed: March-June 2020. The authors' conclusions are supported by the opinion expressed by a number of researchers, according to which the main negative effect of the current crisis will be in 2020, and starting from the next year, without any reference to the oil price, the adaptation of the economy and economic entities to the existing conditions will begin [27].

Thus, it would be possible to assume that the indicators of sales volumes in the residential real estate market by the end of this year will be comparable with last year's results in the segment of business class, will be adjusted within $10 \%$ in the segment of comfort plus and not less than $15 \%$ in the mass segment, even despite the reduction of mortgage rates.

However, the current situation does not allow making any forecasts without reservations, as the public remains in a mood of general uncertainty, which is a constraint on decision-making even for a financially stable audience, not to mention the fact that spring events hit the personal budget of one third of the country's population. It is important to understand that the transformation of the real estate market in the post-Pandemic period will be determined by the financial capacity of buyers and the state of the construction industry.

At the entrance to the pandemic funnel, construction organizations had a rather weak potential for business activity, so their chances to resist the primary and even more so the subsequent associated negative events in the economic space are minimal.

The accentuated refraction of the business climate dynamics of the construction segment, which has developed in recent years, reflects a seriously worsened value of the main composite indicator - the index of entrepreneurial confidence, which, having accumulated the pandemic nature of the changes, fell from $-15 \%$ to $-24 \%$ (Fig. 1).

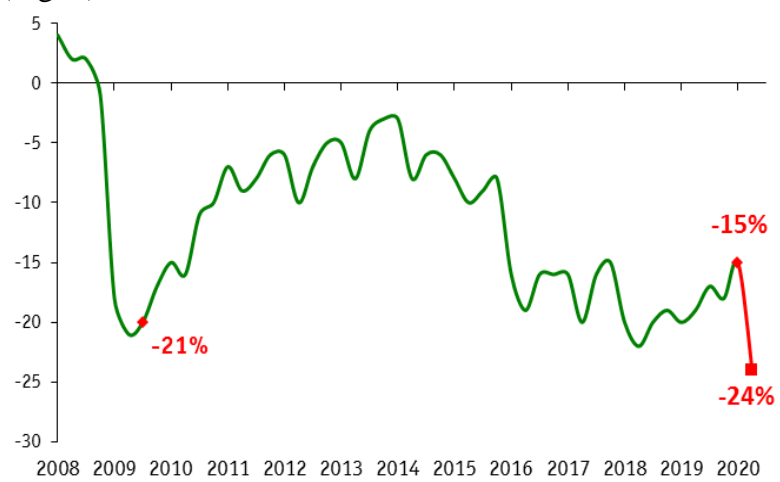

Figure 1 Dynamics of entrepreneurial confidence index in construction segment $[28,29]$

Each of the components of the Entrepreneurial Confidence Index (order portfolio assessment and expected change in the number of employees) had a destructive impact on the change in its dynamics in the construction segment in the second quarter of 2020 (Fig. 2).

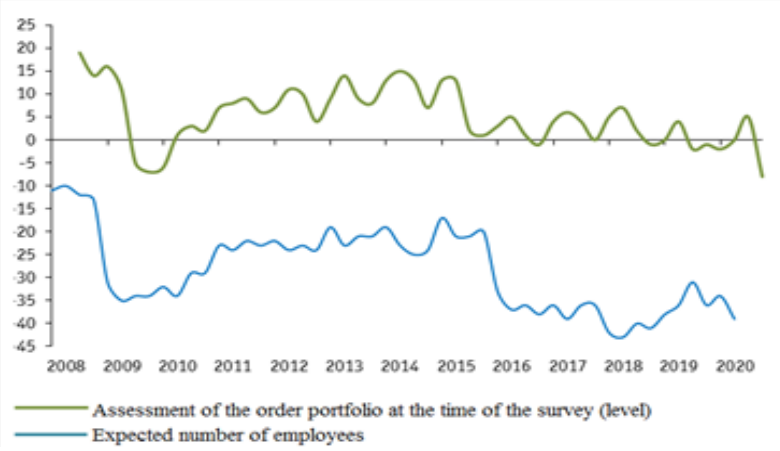

Figure 2 Dynamics of components of the entrepreneurial confidence index in the construction segment (balances, $\%)[28,29]$

The share of construction companies in which the process of reducing the number of concluded contracts - the order book - started in the second quarter compared to the first quarter of 2020 increased from $26 \%$ to $30 \%$. During this period, the intensity of the reduction in the physical volume of work increased, which covered more than a third of construction companies compared to $28 \%$ in the first quarter of 2020. (fig.3). 


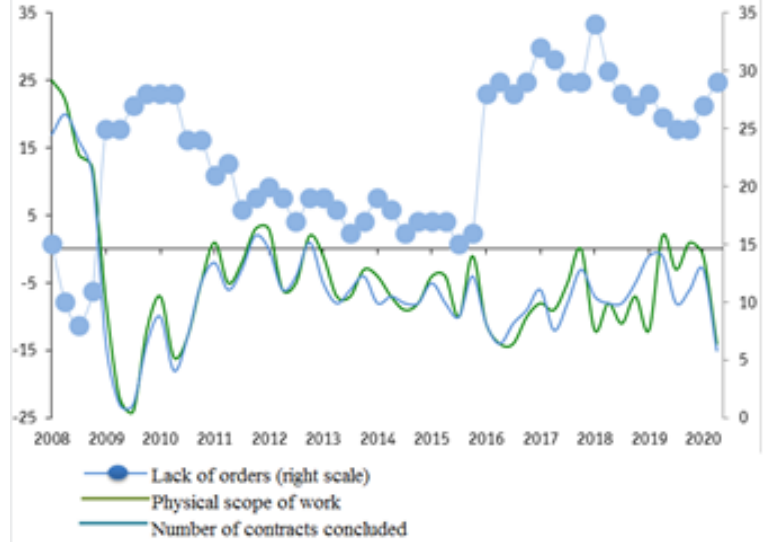

Figure 3 Dynamics of evaluation of physical scope of work, number of concluded contracts and limiting factor "lack of orders" (balances, \%) [28,29]

The coronavirus pandemic provoked an impressive reduction in the number of employed in the construction sector, the rate of staff attrition doubled in the 2 nd quarter
2020 (the balance of the number of employees estimated was $(-16 \%)$ against $(-8 \%)$ in the 1 st quarter). The unfolding trends determined the negative vector of changes in the main indices of the financial block of the construction sector.

It should be noted that due to somewhat delayed specificity of the response of the construction sector to shocks, its inertia is still quite high, sectoral nuances of the financial component presented by the authors of the above conclusions are based on the data, which in their dynamics do not contain the entire scale of the coronation crisis consequences. Therefore, undisclosed pandemic effects that are highly likely to develop and provide an unfavourable scenario for the construction segment in at least the next three months.

Real estate prices are an indicator of the state of the real estate market, let us consider the dynamics of price changes on the primary and secondary housing markets (Fig. 4). And let us assess the market prospects until the end of 2020.

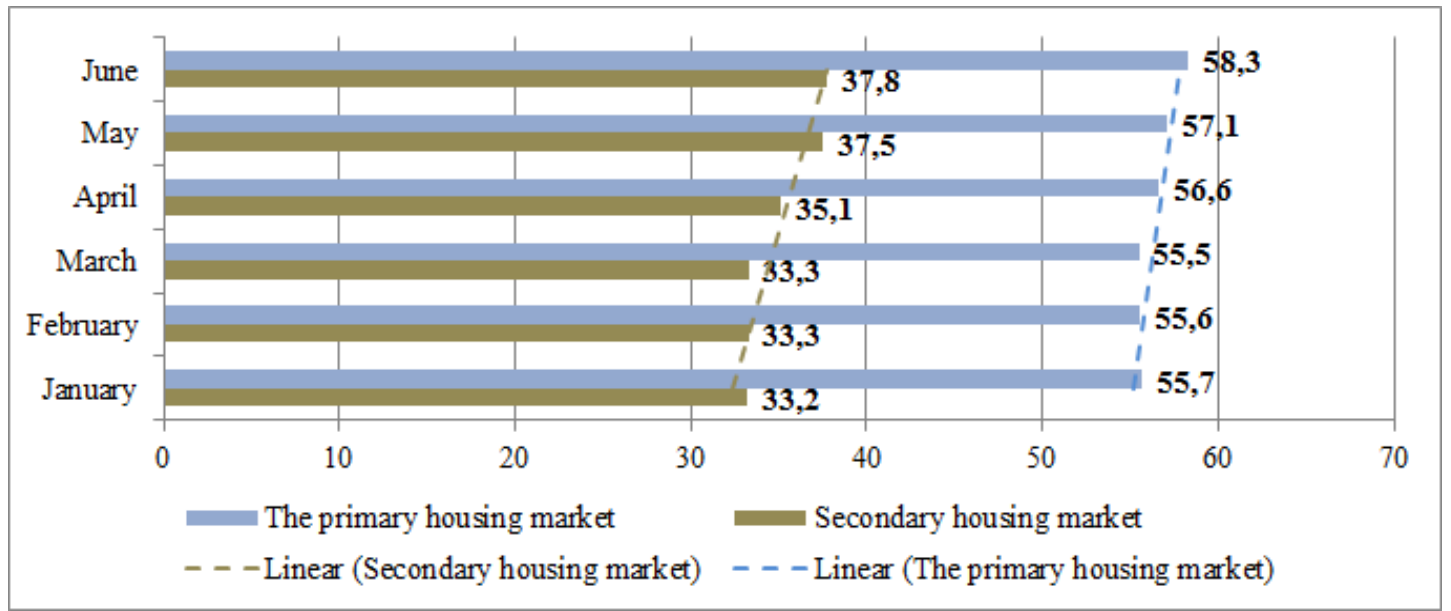

Figure 4 Dynamics of housing prices in the primary and secondary residential property market, thousand rubles per 1 sq. $\mathrm{m}$. [29].

The ruble depreciation and the supply of the coronavirus infection by Russian President Vladimir Putin to raise the tax rate on income going abroad from $2 \%$ to $15 \%$ stimulated the growth of demand for real estate on the new buildings market in late March and early April 2020. The restrictive COVID-19 measures introduced on April 13, 2020 not only halted construction works, but also made it impossible for potential buyers to look through apartments.

The system of online sales organized by developers did not solve the problem of reduced sales in the primary housing market. Builders' expectations of a sales revival after the restrictions were lifted did not materialize. Most buyers who prefer the traditional offline procedure for buying a home, to the offices of developers have not reached. For example, in Moscow, the number of transactions with primary real estate in May fell by $20 \%$ compared with April.
The secondary housing market was in a worse situation than the primary market. Citizens were on self-isolation, which did not give them the opportunity to see the property for purchase. The temporary closure of the Multifunctional Centres made it impossible to register the purchase and sale on the residential real estate market. As a result, the secondary housing market was "completely frozen". Proposed by the Russian government anti-crisis measures in the form of preferential mortgage at $6.5 \%$ for the purchase of housing in new buildings reoriented the demand from secondary housing in the segment of new buildings, as the weighted average mortgage rate for the secondary housing market is $8.32 \%$. The existing secondary housing market preferential mortgages available to a limited number of families: families with children and disabled children, combined with the observed dynamics of real estate prices in the months when the prices for primary housing are lower than for secondary housing 
(especially in Moscow), exacerbates existing problems and drives the buyer's demand in the segment of new buildings.

Reduced purchasing power of the population, a rush of demand before self-isolation and unfavorable conditions in comparison with the primary housing market, make us talk about stagnation in the secondary market and a decline in supply prices. By the end of 2020, the expected price reduction on the secondary housing market may be estimated at $15 \%$ by the beginning of the year.

There are common reasons for the primary and secondary housing market, which may affect further development of the situation. Thus, the next reduction of the key rate by the Central Bank of Russia to 4.25 per cent will be followed by a decrease in the interest rate on deposits by commercial banks and, as a result, a decrease in the motivation of citizens to place free cash on deposit accounts of banks. Federal Law No. 35-FZ of March 1, 2020 amended the legislative acts of the Russian Federation on issues related to the disposal of maternity (family) capital. The amount of maternity (family) capital has been increased, new possibilities for the use of IIC funds have been established and the period of validity of the maternity (family) capital programme has been extended. In 2021, the country introduced a 13 per cent tax on income from bank deposits and investments in securities exceeding 1 million roubles. In such a situation, the free financial resources of the population of the country with a high degree of probability will not place on a deposit, but will invest in real estate, as it is a true and proven option for years of money deposit.

The package of anti-crisis measures announced by the Government of the Russian Federation in mid-March 2020 to support the housing construction sector contains special approaches to the application of financial sanctions within the framework of the legislation on shared construction for delays in the performance of obligations by developers in the construction of housing in 2020, in addition, a temporary moratorium on the recovery of funds from enforcement proceedings related to the improper performance of obligations by the developer has been introduced, and a temporary ban on the inclusion of apartment buildings in the register of apartment buildings has been introduced. The list of systemically important buildings includes 54 construction companies that meet such criteria as the volume of construction of residential and non-residential buildings of at least 400.0 thousand square meters and revenues for 2019. - at least RUB 10 billion. The total volume of objects under construction by the organizations included in the list is $\mathbf{5 3 . 5}$ million square meters.

Along with the factors that can positively affect the recovery of the residential real estate market, there are also negative ones, which include, first of all, salary cuts and job losses. According to the estimates of the Federal State Statistics Service, real money incomes in the second quarter of 2020 decreased by $7.7 \%$ compared to the corresponding period of 2019, in the first half of 2020 compared to the first half of 2019 . - by $3.1 \%$ (Fig.5).

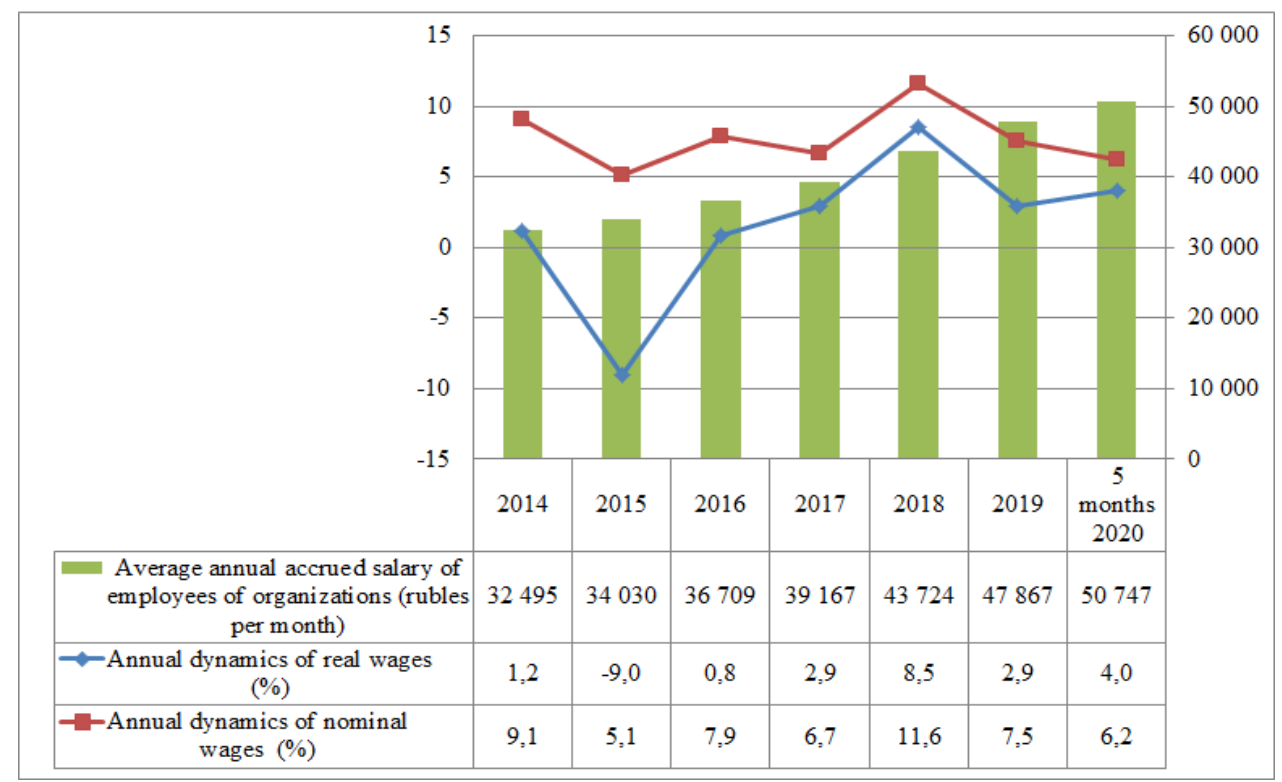

Figure 5 Dynamics of average monthly nominal and real accrued wages of employees of organizations [29]

In May 2020 the average monthly accrued salary of the employees of organizations made 50,747 rubles and as compared with the corresponding period of 2019 it increased by $4.0 \%$ (in January-May 2020 - by $6.2 \%$ ).

In June 2020, the number of employees aged 15 and over made 74.7 million, of which 70.1 million were classified as economically active and 4.6 million as unemployed meeting the criteria of the International Labor Organization (Fig.6). 


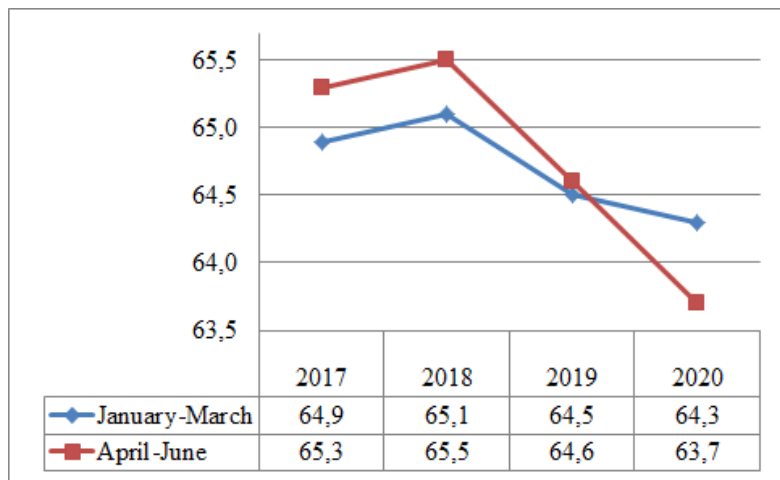

Figure 6 Employment rate dynamics of the population aged 15-72 years in the Russian Federation, average for three months 2017-2020. [29]

According to Rosstat, the number of poor people was in January-March 2020. 18.6 million people or $12.6 \%$ of the total population. As compared to the same period of 2019, the share of people with incomes below the minimum subsistence level decreased by $1.7 \%$. Such a decline in the number of poor, according to the authors, is largely due to the fact that, according to Rosstat's estimates, the cost of the minimum necessary for life set of goods and services has remained practically unchanged over the year, the cost of living minimum accepted by Rosstat to calculate poverty in the first quarter of 2020 amounted to $\mathrm{Rb}$ $10,843.0$ per month, that is $+0.8 \%$ per annum. The conclusion, to put it mildly, is controversial, given that inflation at the end of March 2020 was $2.5 \%$ per annum and food inflation was $2.2 \%$ per annum.

The unemployment rate (ratio of the number of unemployed to the number of labor force) in June 2020 was $6.2 \%$ (Fig. 7 ).

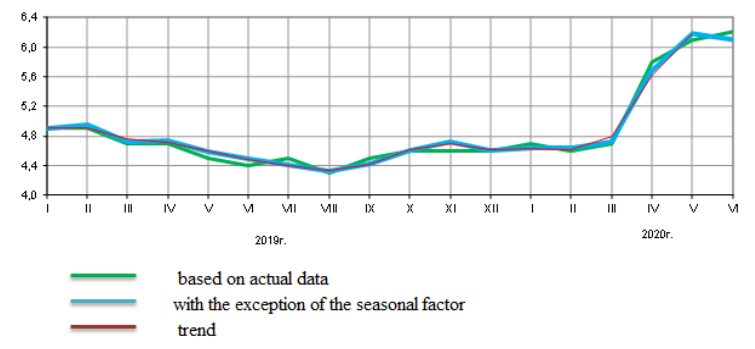

Figure 7 Dynamics of unemployment rate of the country's population aged 15 years and over (in $\%$ of the labor force) [29].

Salary cuts and loss of employment for many citizens have affected the solvency of the population. Decrease in real disposable money incomes of the population and transition of the majority of households from the consumer model of behavior to the savings model will immediately lead to reduction of housing construction and narrowing of the residential real estate market. According to Rosstat, as early as May 2020 the volume of commissioning of the total area of residential premises fell by almost $25 \%$ as compared to the corresponding period of 2019. Given the fact that there will be a favorable scenario and the beginning of recovery growth will have to be in the III-IV quarters of this year, the annual losses of housing construction in 2020 will be about $10 \%$. It is also necessary to take into account the fact that in construction in January-April 2020 there were $32.9 \%$ of loss-making organizations out of the total number of them, some of them most likely have a high level of credits and a considerable volume of unfinished construction. The volume of unfinished construction in bankrupt organizations is currently estimated by experts at 10 million square meters and this will not allow to consider the departure of such organizations from the construction market as a mechanism of "creative destruction". The growth of construction in progress, for the completion of which, according to experts, requires more than 500 billion rubles, especially for organizations working without escrow accounts, can cause a negative reaction from the buyers of housing, as they in such a situation acquire the status of deceived shareholders.

These problems in the housing construction sector are aggravated by the situation with the hiring of migrants in construction professions, logistical difficulties due to the suspension of cargo transportation, especially import supplies and possible breaks in supply and distribution chains.

\section{CONCLUSION}

This situation is not conducive to the recovery of the residential real estate market and to sales growth.

Analyzing the data of the Federal State Statistics Service, expert assessments published in mass media, main measures taken by the Russian government in the current situation, existing and potential economic consequences of the pandemic for the Russian economic system, the authors, taking into account the experience of recovery from the crises of 1998, 2008 and 2014, tried to predict the consequences of COVID-19 for the residential real estate market.

Taking into account that on the eve of the 2008 crisis the Russian economic system was in a state of economic recovery, and the period preceding COVID-19 is characterized as a period of economic stagnation accompanied by a drop in real incomes of the population and its lending, the recovery of the residential real estate market will be protracted. It is forecasted that during the current year and the beginning of 2021 the growth rate of the average residential property price will outpace the inflation rate. In the second half of the year the market is likely to stabilize, the growth rate of the average price of residential real estate will be approximately at the level of inflation.

A more active role of the state support for the residential real estate construction sector in the form of subsidized mortgage interest rates (extension of the mortgage subsidy program with an even lower rate, increasing the credit limit), development of support programs for certain categories of citizens, compensation for the costs of epidemiological measures will have a positive impact on the recovery process of the residential real estate market. 
Russia's economy is currently in an uncertain state, which is dependent on many factors. Covid-19 has put up huge barriers to the development of many areas, including the residential real estate sector: a decline in personal income, the projected growth of the unemployed, estimated by some experts at 15 million people, a multiple reduction in the number of small businesses. It takes a lot of resources and time to establish the previous work, and it is difficult to assess the real scale and consequences of which at the moment. Time will tell how the residential real estate market will survive the pandemic and what damage it will suffer.

\section{REFERENCES}

[1] S.Yu. Glazyev, About the root causes of the growing chaos and measures to overcome the economic crisis 23/04/2020, Electron resource.

[2] O.A. Guzhova, Modern tendencies of the construction industry development, Traditions and innovations in construction and architecture. Socialhumanitarian and economic sciences: Collection of articles, Samara, 2015. pp. 394-399.

[3] O.A. Guzhova, Innovative technologies in construction, Innovative strategies of management development in construction and urban economy. Samara, 2018, pp. 178-184.

[4] O.A. Guzhova, Cost optimization in construction (in Russian), Innovative strategies of economy and management development, Samara, 2017, pp. 53-59.

[5] O. Trends in the Russian construction industry development under the strategy of the state economy security, E.O. Proshkina, A.V. Tumashova, From scientific ideas to business development strategy: a collection of articles and research papers of students, masters, post-graduate students, young scientists participants of the international conference on "Financial security of business and state: problems and solutions", M., 2016, pp. 479-484.

[6] R. M. Cyert, J. G. March, A Behavioral Theory of the Firm. 2nd ed. Blackwell: N. Y. 1992

[7] P. George, Huber The Necessary Nature of Future Firms, Attributes of Survivors in a Changing World, 2003.

[8] S. Jeffrey, Russel Perspectives in civil engineering: commemorating the 150th anniversary of the American Society of Civil Engineers: Reston (Va.): ASCE, cop. 2003.
[9] E.P. Zharoronkov, E.P. Logistics in construction: a textbook, Novosibirsk: SGAPS Publishing House, 1996, 88 p.: silt.

[10] V.N. Stakhanov, E.K. Ivakin, Logistics in construction: Textbook, Moscow: "Prior Publishing House", 2001, P. 176.

[11] G. Weldon, We are waited by turbulence, Electronic resource.

[12] S.Y. Glazyev, Economy of the future. Does Russia have a chance? Book World, 2017.

[13] S.Y. Glazyev, Russia Needs the Right Theory of Economics, Electronic resource.

[14] G.P. Zhuravleva, N.V. Manokhina, New rules of the game in conditions of the economic turbulence (in Russian), Vestnik of Saratov State University of Social and Economic Sciences. 2013. №5 (49),Electronic resource.

[15] S.G. Kirdina, To rethinking of the principle of methodological individualism. Moscow: Institute of Economics RAS, 2013.

[16] V.N. Livshits, Basics of System Thinking and System Analysis. Moscow: Institute of Economics RAS, 2013.

[17] Y.Y. Olsevich, Modern crisis of "mainstream" in the estimates of its representatives (preliminary analysis). Moscow: Institute of Economics RAS, 2013.

[18] S\&P confirmed sovereign ratings of Russia, forecast - "stable"// "FINAM". 20.07.2020., Electronic resource.

[19] Information from the Ministry of Construction, Housing and Utilities of the Russian Federation of April 24, 2020. "The Law Commission approved the list of system-forming organizations of Russian economy in the sphere of construction and housing and communal services", Information and legal portal "Garant.ru", Electronic resource.

[20] Federal Law "On Mortgage (Pledge of Real Estate)" dated July 16, 1998 N 102-FZ, Electronic Resource.

[21] G. Popov, On Economic Crisis of 2008, Voprosy ekonomiki, 2008, 12, pp.112-119.

[22] Yu.M. Voronin, Russia and crisis-2008 (in Russian), Finance: Theory and Practice. 2009. №5, Electron resource. 
[23] V.B. Kondratyev, Crisis of 2014 in Russia as a Result of Vices of Economic Policy, Prospects, Electronic resource.

[24] Housing Market Decline in Crisis Years: 1998, 2008, 2014, Russia under Construction. 26.10.2018, Electron resource.

[25] Federal Law "On Participation in Equity Construction of Apartment Houses and Other Real Estate Objects and on Amendments to Some Legislative Acts of the Russian Federation" dated 30.12.2004 N 214-FZ, Electronic Resource.

[26] G. B. Pivovarova, T. V. Tretyachenko, Domestic market of residential real estate: problems and prospects of development, Humanitarian and socioeconomic research in modern conditions: collection of articles of teachers and post-graduate students, Moscow: Znanie-M, 2020, pp.58-66.

[27] Monitoring of the economic situation in Russia: trends and challenges of socio-economic development. 2020. No. 18 (120). June / Under edition of Gurevich V.S., Drobyshevskiy S.M., Kolesnikov A.V., Mau V.A., Sinelnikov-Murylev S.G.; E.T. Gaidar Institute for Economic Policy, Russian Academy of National Economy and Public Administration under the President of the Russian Federation. 84 c. E.T. Gaidar Institute for Economic Policy, Russian Academy of National Economy and Public Administration under the President of Russian Federation. 84 p., Electronic resource.

[28] Business climate in construction in the first quarter of 2020, M.: NIEU WSHE, 2020, P.16.

[29] Socio- Economic Situation of Russia, Federal State Statistics Service Moscow January-May 2020, Electronic resource. 